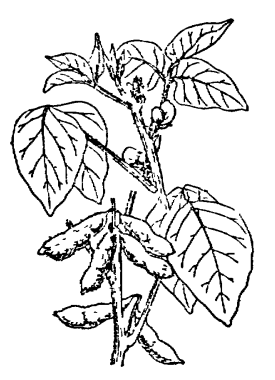

わが国の 1980 年の大豆総供給量は 4,984 千トンであ る.そのうち，国産大豆の生産量は 192 千トン，それ以 外は，85\% が米国，2\% が中国から（表 1)，また残余 はブラジル，カナダなどからの輸入大豆によりまかなわ れている、したがって，自給率は $4 \%$ であり，また食品 用大豆需要量 617 千トンに対しても，自給率は $30 \%$ に とどまっている(1).

大豆の用途別使用量和よび食品用原料大豆の種類 (1981 年)(1)を図1に示した. 米国輸入大豆のほとんどは 2 等級黄大豆であり, 製油用とともに, 精選後, オーデ ィナリイ大豆として豆腐などに使われている。 また，生 産地（インディアナ, オ八イオ, ミシガン) 指定大豆が IOM 大豆として豆腐関連の加工用・味噌・納豆用に, 特定品種が バラエティ大豆として豆腐・味噌用に， ま た, 白目大豆 (一部カナダ産) が, 中国大豆の輸入量と のかねあいに応じて輸入され，味噌用に使われている. 中国大豆は味噌・納豆用として好適であるが，輸入年に より，品質および供給量に安定性を欠き，米国産大豆に かえられつつある. 国産大豆は良質ではあるが供給量お よび価格の面に問題があり, 納豆・味噌・煮豆などの品 質の高い製品用に使われている。このように, 原料大豆
平 春 枝 農林水産省食品総合研究所

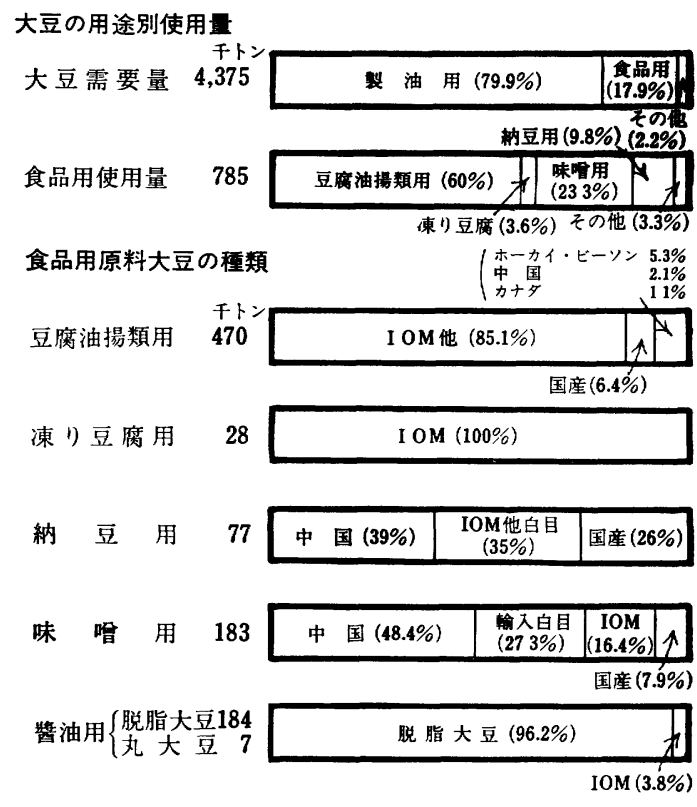

図 1 大豆の用途別使用量と食品用原料大豆の種類 (1981 年)

の生産国は多岐にわたり，それぞれの品質に特徴をそな えている，ここでは，米国，中国，わが国の大豆を中心 に解説するとともに, 成分組成・加工適性の特徵とそれ らの変動要因についても言及した い.な拉，中国大豆は東北地区産が 総生産量の $35 \%$ を占め, 輸出用で るあるため, これについて述べる。

\section{1. 大豆の性質}

大豆の作物としての著しい特徵 は, 育種・品種・栽培・品質との関 連が深いので，それらを略記する。

* FAO : Production Year Book, 1980, ** FAO : Trade Year Book, 1980, **** 外国貿易年報表 


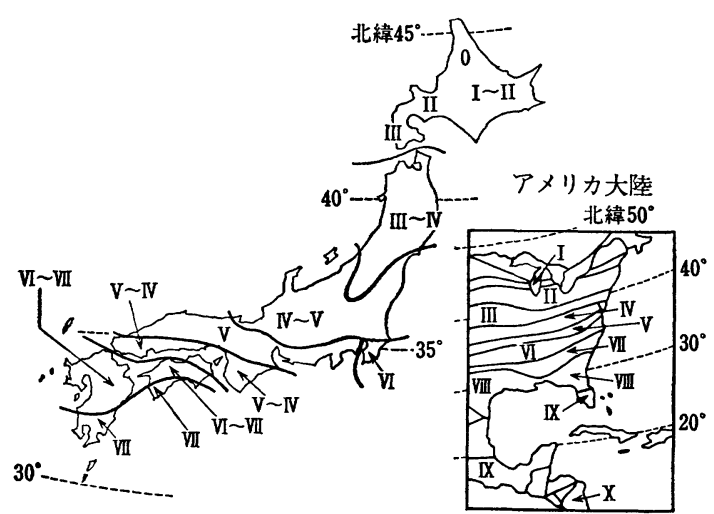

図 2 主要成熟期群品種の地理的分布

(アメリカの成熟期群分類による)

\section{1）地域適応性}

短日植物である大豆は開花・結実が日長に対して敏感 であり，また温度も影響し，緯度からみた 1 品種の栽咅 地適応範囲は狭い。このため, 生態型の異なった大豆が 緯度や高度に応じて分布し，さまざまな品種に分化して いる. アメリカの成熟期群分類を用いて米国およびわが 国の品種の地理的分布をみると，高緯度に分布し早期に 成熟する品種 (0.I·II 型：夏大豆，早生に相当), 中間 型 (III $\cdot \mathrm{IV} \cdot \mathrm{V}$ : 中間型, 中生に相当) および低緯度地域 の晚期成熟品種 (VI·VII 型 : 秋大豆, 晚生に相当) が ある(図 2) (2).

\section{2）形態上の特性}

大豆の生育に扣いて, 草型, 蔓化, 伸育性, 葉の状態 が品種・栽培条件で異なる。根には根粒菌が共生する。 子実では粒の大きさ, 粒型, 種皮色, 目 (へそ) の色, 裂皮， しわの程度の品種間差が大きく，加工適性も異な る.

\section{2. 育種と品種}

\section{1）米国大豆}

1804 年に米国に初めて紹介されてから 1920 年代ま で，大豆は粗放農業に適した作物としてすき込及，放 牧，乾草用などに使われていた。この間，米国農務省は 諸外国，とくに中国，日本，朝鮮から 3,000 種以上の優 秀な品種を導入し, 子実用大豆としての品種改良を重放 ている．前述の上うに，大豆は各地域に適合して多くの 品種が分化しているため, 類似の緯度に位置する前記諸 国から品種を導入しただけで，短期間に栽培が可能とな

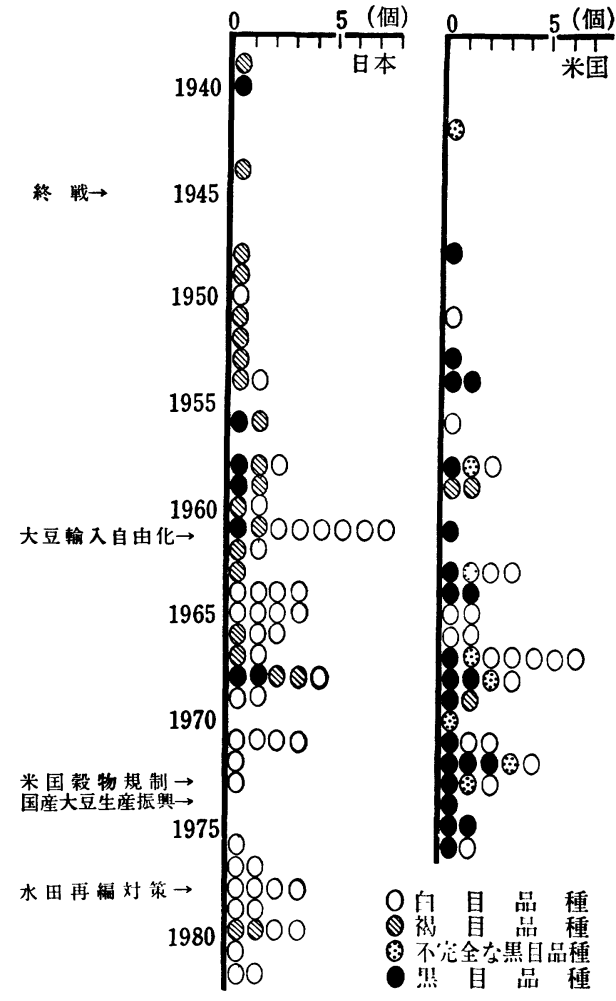

図 3 日本大豆農林登録品種および米国主要大豆品 種の育成年次と子実の性状

ったのである.したがって，1942 年第 2 次世界大戦によ り東南アジアからの油糧資源の供給が絶たれた時，米国 大豆は油糧資源としての子実用に切り換えられ，1945 年 には栽培面積の $84 \%$ が子実用となり，衣がえが終って いる.

子実用大豆の初期の育種目標は多収, 高脂質含量, 機 械收穫適応性（裂萊抵抗性，難倒伏性）品種の育成であ り，1936 年には各成熟群について達成し，普及品種の ほとんどが 21〜22\% の高脂質含量となった。また，コ ンバイン収穫が可能となり, 農作業の能率化により生産 費が引き下げられ，子実価格の低下が実現された。 その 後, 大豆栽咅の普及に伴い病害虫の被害が多発し, 1950 年代は病虫害抵抗性の付与に育種の重点が括かれ，従来 からの普及度の高い優良品種の 特性を残し 耐病性だけ を付与し，公開年の 記号を付けて普及されている（例 1963 年公開：ハロソイ 63 など)。また，ダイズシスト センチュウ抵抗性因子の黄色粒品種への付加が 1963 年 に成功し, 実用化されている。一方, 米国内油糧原料以外 の新用途の開発と, 日本向け輸出量の増大に対応して, 
食品用白目高タンパク質含量大豆の 育成（図 3)，大豆油の安定性を増す ための脂肪酸組成の改良なども進め られている。 その活か，収量不振に 対応して，草型の改良汇よる多収性 品種の育成や根粒菌関連の育種が行 なわれている。

育種組織は, 農務省 (USDA) 農 業研究サービス（ARS）を中心に, 北東部, 北中部, 南部, 西部各地域 に研究所, 実験所または分場を設置 し, 育種・栽培の研究を行なってい る.また, 育種センターが北東部， 北中部, 南部, 西部の大学内にあ り, 小規模育種事業も各地の大学 で, 25 州立農試では育種事業と栽 培の研究が，それぞれ農務省との密 接な連絡のもとに行なわれている. 育成された有望系統は，成熟群別に 28 州 96 個所の系統適性試験地にお いて生産力なぞの地方適応性が検定 されている，なお，農務省が植物導 入計画により全世界から導入した品 種は 1 万点以上に及び，北部拉よび 南部の地域実験所において一般特 性, 成分含量, 必要に応じた病虫害 抵抗性などの詳細な調查が行なわれ た後，育種材料として資料が付さ れ，育種家が利用し易い形に整理さ れて北部地域大豆実験所に保存され ている．育種方法としては，純系分 離, 交雑育種, 突然変異育種などが用いられている( ${ }^{(3 \sim 6)}$.

栽培品種の成熟品種群 (カッュ内は栽培地)は，0 (ダ コタ, ミネソタ, 北部ウィスコンシン各州), I (サウスダ コタ, ミネソタ, ウィスコンシン, ミシガン州南部，ア イオワ，イリノイ，オ八イオ州北部），II〜IV（北中部 の諸州の南部とそれと同緯度の地域), V〜VIII (上記よ り南の地域) で, 北・中部でュルソイ, ウイリアムズ, ウエーン, 南部でブラッグ, フォレストなどの品種の栽 培面積が広い. 17 州合計作付比率では, ウイリアムズ, コルソイ, ブラッグの 3 品種で約 $30 \%$ を占め, 上位
品 種 名

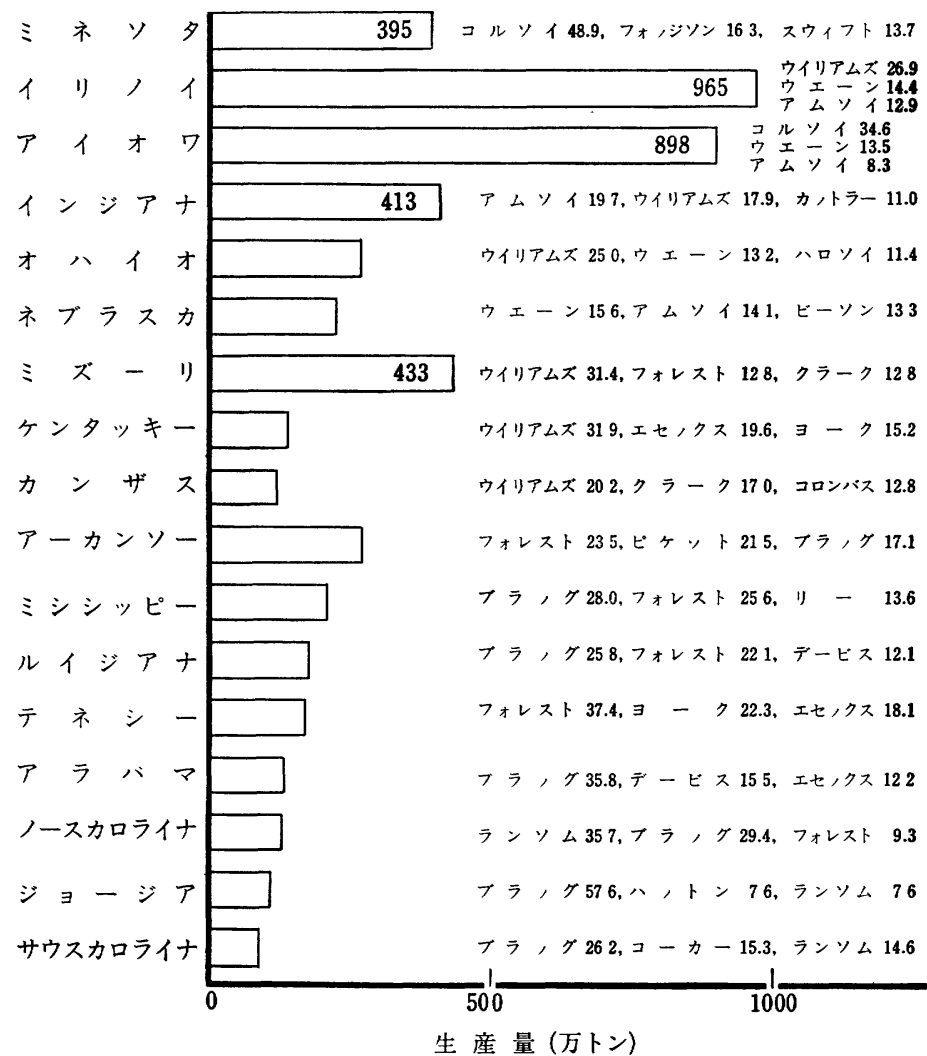

図 4 米国主要州大豆生産量 (1981年) と主要大豆品種の収穫面積割合 (1977年・\%)

表 2 日本, 中国, 米国, ブラジル大豆の品質比較 $(\%)$

水 分多質** 脂 質 灰分夾雑物 割 豆損傷豆 酸 価

\begin{tabular}{lllllllll}
\hline 日 本 大豆 & 12.50 & 38.48 & 16.80 & 4.93 & & & & \\
中 国 大 豆 & 12.50 & 35.72 & 17.26 & 4.44 & & & & \\
米 国 大 豆 & 11.70 & 35.77 & 18.88 & 4.74 & & & & \\
米 国 大 豆* & 11.96 & 36.06 & 19.14 & & 1.74 & 10.21 & 1.87 & 1.71 \\
ブラシル大豆* & 11.39 & 35.69 & 20.38 & & 1.08 & 12.40 & 1.51 & 1.75 \\
\hline
\end{tabular}

* 日本油料検定協会, ${ }^{* *} \mathrm{~N} \times 6.25$

10 品種で $64 \%, 26$ 品種で $88 \%$ を占める(7). 各州の 栽培品種数(7)は少なく（図 4)，このことが米国大豆の品 質の均一性に結びついている，米国大豆は製油を主目的 とした小粒黒目品種が主流であり ${ }^{(8)}$ ，大粒品種は単収の 低いことと生産費の高いことが支障となり，生産量が低 下している，米国大豆の成分組成は脂質含量が高く，タ

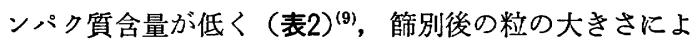
り成分組成が異なる ${ }^{(10 \sim 12)}$. 


\section{2）中国大豆（東北地区）}

安定多収・良質大豆育成の各地共通目標とともに，機 峨化適応性，高脂質含量 (22\% 以上)，また他作物との 間作が広く行なわれるために，耐陰性，間作適応性がと りあげられているのが特徵的である. 耐旱性, 軽アルカ リ土壌適応性も考兄られ，百粒重については 16〜20 g を理想としている. 育種は, 省農業科学院または出先の 研究基地で行なわれているが，人民公社，生産大隊，生 産隊に打ける選抜・育成も成功を収めている。育種方法 は交雑育種が主であるが，突然变異育種の比重も高い， 品種は中国の表現では “春大豆”（春播する大豆）にあた り, わが国の北海道品種や東北地方の早・中生品種と相 似した熟期（図 2) である. 主要品種はかつては満倉金, 元宝金，金元 1 号などであったが，近年育成された品種 にかえられつつあり, 黑竜江省南部では黒農 26 号（多 肥, 多収型, 密植適, 草型良; 栽培面積の約 $1 / 3$ を占め る）を筆頭に, 黒竜 16・10.11 号, 吉林省では吉林 3 号 (間作適品種; 栽培面積多い), 早豊 1 号 (多肥密植適品 種), 吉林 13 号, 遼寧省では鉄豊 3.5・8・18.19 号など が重視されている(13).

中国大豆の総生産量 10,000 千トンは, 1950 年以来汪 とんど伸びをみせない（FAO 生産統計, 表 1)。この理 由としては単収の低迷とともに, 中国政府が自国の食輄 需要に対応して米, 小麦, その他農産物の生産を優先し ているためとみられている. 成分組成は, 米国大豆に比 べて脂質含量が，またわが国の大豆に比べてタンパク質 含量がともに少なく（表 2) ${ }^{(9)}$ ，煮え易さの点から味嗊・ 納豆原料として使われてきた。 しかし，供給が不安定な ことが多く，米国産大豆への転換が行なわれている(7,8).

\section{3）わが国の大豆}

わが国の戦前〜戦後（1960 年）に括ける育種目標は， 生産の安定性（病虫害・不良土壤への抵抗性）に重点が おかれていた，現在の基本育種目標は良品質・多収・機 械栽培向品種の 育成であり，育成母本には優良育成品 種・系統, 在来種とともに, 而病虫性・機械化栽培適応 性・高成分育種などについては新遺伝子の導入を国外品 種に求めている.

品質育種は大粒白目子実の育成であり, 輸入大豆との 競合をさけるために食品用大豆としての特性をもたせて いる. 1966 年から 1982 年までに育成された 34 品種
は, 黒目 2 品種 (内 1 品種はごく淡色), 褐目 6 品種を 除き中粒〜大粒白目の品種であり（図 3)，また，東北地 方の主要品種はすべてが白目となり，銘柄統一による流 通上の有利性をもたせる方向が打ち出された．種皮色， 裂皮，乙わなど外観の向上とともに，加工業界からの要 請も 反映して 納豆加工用小粒品種スズヒメ（1980 年育 成）も育成された．成分育種では高タンパク質含量（50 $\%$ 以上, 乾物值), 高含硫了ミノ酸含量品種の育成も試 みられた。

単収の向上については多肥密植性が，収量の安定につ いては耐冷性, 耐倒伏性, 耐旱性, 耐病虫性の育種が行 なわれ, 育成品種の平均生産量は $261 \mathrm{~kg} / 10 \mathrm{a}$ を示し, こ の数值を最近 10 年間の全国平均收量 $130 \mathrm{~kg} / 10 \mathrm{a}$ に比 ベると育成効果の著しいことがわかる．たとえば，1966 年に東北農業試験場刚和野試験地においてネマシラズに コバルト 60 の 線を照射し，その突然変異体より育成 したライデン，ライコウは，ネマシラズのすぐれた形質 であるダイズシストセンチュウ抵抗性などの形質を保持 し，收嚄時期を早めることのできた安定多収品種であ る. また, 機械化適応性品種（非蔓化性, 強秙性, 耐裂 萊性，最下位結萊高）の育成により，タチスズナリ， フ ジミジロ，ワセコガネ，スズヒメなどが誕生し，省力化 による大豆生産費の低下を目指している。 その注か，気 象条件や前後作物々の関連で, 早生化・晚播適応性な ぞ，各育成地が必要に応じて対応し成果をあげている.

わが国で近代的育種体制がとられるようになったのは 1930 年代に入ってからであり, 1950 年代には農林省研 究機関 (東北農業試験場大館試験地), 農林省 指定試験 地 (茨城: 石岡, 熊本 : 阿蘇, 佐賀), 道 (十勝) - 県立 農業試験場（新潟など）が単独で育種を行なっていた。 現在, 育成のために設けられた指定試験地は以下の 5 場 所であり, 生態別に分担し, 育種基本計画に沿って地域 適応優良品種の育成が進められている. 北海道立十滕農 業試験場 (北海道東部・北部向 : 耐冷性強, 機械化耤培 向, シストセンチュウ抵抗性強), 北海道立中央農業試 験場 (北海道中央部・南部向 : 矮化病強), 東北農等試 験場刈和野試験地（東北地方向：ンストセンチュウ・モ ザイクウイル ス抵抗性強, 早生化), 長野県総合農業試験 場中信地方試験場 (関東 - 東山・北陸 - 東海 - 近畿地方 向: 晚播適応性, 耐旱性, 立枯れ性病害強), 九州農業 試験場作物 2 部 (中国-四国-九州向 : 虫害難). 育成 


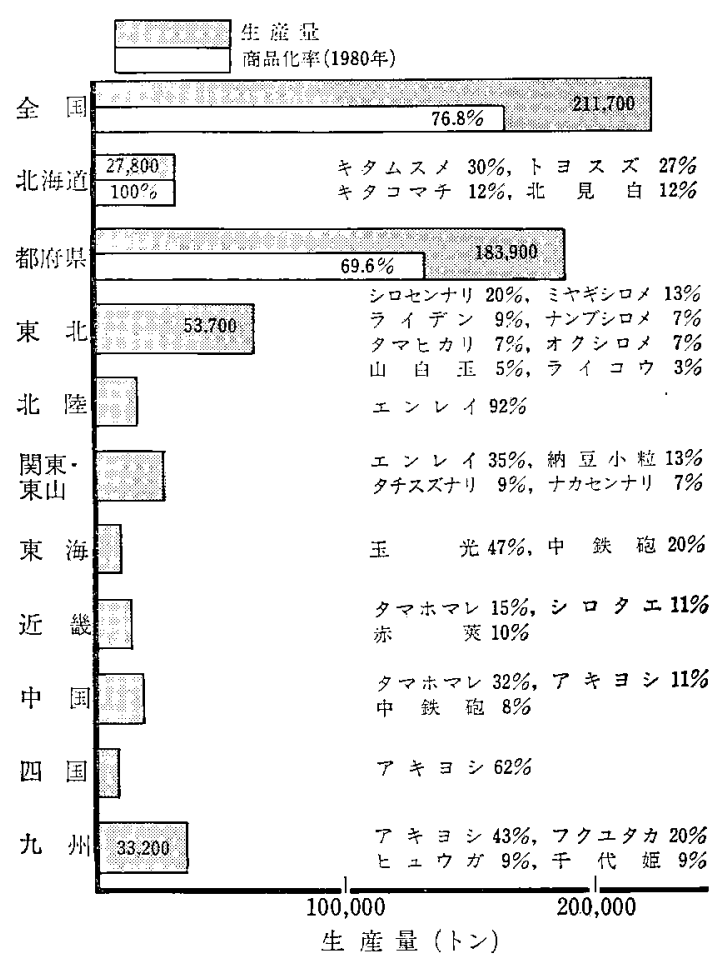

図 5 日本大豆生産量と主要品種の作付比率 (1981年, \%)

系統中有望な系統は，指定の県農業試験場に括いて地域 適応性が，特性検定試験として病害・センチっウ害・虫 害抵抗性の有無々程度が関係農業試験場で調查されてい る.また，奨励品種選定のための青成系統生産力検定試 験が，全国 20 個所以上で行なわれている(1,14,15). 育種 万法は交雑育種が大半を占め, 系統法と集団育種法が併 用され，純系分離法户智然変異育種法も利用されている.

わが国は地理的に細長く位置し，標高差の異なった地 形で大豆が栽培されているために，栽培面積の割に品種 が著しく分化している（成熟期：0〜VII，図 5).1981 年飞農林水産省に都道府県から報告された奖励品種 数 ${ }^{(1)}$ は, 北海道 15 , 東北 20 , 関東 17 , 北陸 7 , 東海 6, 近畿 8, 中国・四国 14,九州 14 と多様で㐫る.日 本各地の大豆生産量と主要品種の作付比率を図 5 亿示 した．北海道ではキタムスメ（中粒・黒目），トヨスズ (中粒・白目), 東北では中〜大粒・白目品種, 北陸・関 東・東山ではェンレイ(大粒・白目)，中国・四国・九州 ではアキシシ（中粒・淡褐目）と，品種をまるるる傾向 があり，北海道で $79.5 \%$ ，都府県で $67.9 \%$ が農林登録 品種の作付汇統一されている. 従来, わが国の大豆は栽
培面積が狭く，栽培品種数の多いところから，原料大豆 として要求される定品質・安定供給の性格を欠き，北海 道・東北産の一部除き自家消費，小口販売に回される あのが多かったが，近年その傾同は徐々にか兄られつっ ある．国産大豆は外観上の品質が優れ，タンパク質含量 が高く，脂質含量が低い(表 2) ${ }^{(9)}$ ，乙のため，品質，価 格とのが㐫いから，良品質の味噌，劣豆，納豆などの 原料として使われているが，乞の割合は低い(1)（図 1).

\section{3. 栽培}

大豆の栽培には地域の環境に檤合した品種を選び，正 常な生育により着菼数な多くし，充実させることが增収 に結びっくここれら要因となる大豆の環境条件への適 応性，士壤条件，栽培方法について述べる。

\section{1）気象条件など環境条件}

米国，中国，わが国の大豆栽培を，同緯度上，また同 緯度に和计る主要成熟期群品種の地理的分布 (図 2) からみると，栽培上の共通点が多く，理解し易い。各国 の適栽培地，主生産地は北緯 40 度を中心に分布し，米 国では北東部のコーンベルト地带で総生産量の $66 \%(6)$ が，中国では東北地区で $35 \%$ (13) が，ふが国では北海 道, 東北，北陸，関東・東山地方で $59 \% \%^{(1)}$ が生産され， 量, 質ともに優れた大豆が得られている。.大豆栽培に好 適な気温は $25 \sim 30^{\circ} \mathrm{C}$ 程度であり, 経済的な生産には生 育期間の 最低積算気温が $2,000^{\circ} \mathrm{C}$, 日平均気温として $12^{\circ} \mathrm{C}$ 以上の日数が 120 日以上は必要といわれ，上記の 地域ではこれら必要気像条件に適合している。ぬた，収 量 ${ }^{(16)}$ は冷害, 病虫害, 鳥害, 湿害, 勧草害の影響学受汁 るが，とくに影響の大きい害虫の被害がこれらの地域に 少なく，生産を容易にしていると考穴られている。な お, 病害, センチュウ害, 害虫の発生にほ地域性があり, 防除とともに品種の選択が重要な決め手となっている. 1980 年の単收 $(\mathrm{kg} / 10 \mathrm{a})^{(1)}$ は米国 180 , 中国 104 , 日本 147 で，世界総生産量の $59 \%$ を占的米国の生産量 は，収穫面積の広さに由来する（表 1 ）。

\section{2）土壤条件之施肥}

生育に及伍す土墡の影響は，大豆が強い四肥性の作物 であるために，物理性よりる化学性の活うがはるかた大 きい. 大豆の光合成速度は葉内窒素濃度に 比例し ${ }^{(17)}$, 
窒素施肥による濃度保持が 子実の 生産向上に必要であ $ろ^{(17,18)}$. とくに生長初期の施肥は植物体を作って根粒菌 の着生を促し，開花前期の 窒素追肥は落花や落萊を防 ぎ，增収に結びつく(19)といわれているが，品種により様 相が異なる．リン酸は根粒菌共生品種では有効な 要素 であり，窒素固定を増大させ 植物体の 生育を 旺盛にす $る^{(20)}$. カリは子実の充実之肴粒の減少に役立つ ${ }^{(21)}$. 石灰 は土壤の酸性を矯正するほか，根粒や植物体の生育を促 す.

米国では，基肥として収穫後残された植物体を化学肥 料とともにすき込む施肥法がとられている，また，ほと んどの地域で土壤の有効態養分量と収量との関係が明ら かにされており，土壤テストにより施肥量を決める方法 が簡単に受けられる仕組となっている(3,4). 中国では化 学肥料が収穫物の価格に比べて高価なため, 大部分を自 給肥料（堆きゅう肥など）に依存し，秋耕前に多量の有 機質肥料を施用することが，数年にわたり多収をあげる ための基礎条件となっている(13).わが国では，大豆は土 地を選ばないとして，昔からやせ地でのすて作りが行な われてきた．近年育成され心品種は多肥密植適品種が多 く，栽培様式や肥培管理に 注意が 払われている ${ }^{(22)}$.な お，米国では，他作物之同様に大豆に拈いても微量要素 の欠乏例が多く，とくにマンガンの施肥が必要とされて いる(4).

\section{3）栽培方法 \\ (1) 輪 作}

輪作は地力維持と土㙗伝染性病虫害制御の目的をも ち, 連作障害を受け易い大豆栽培にとっては, 安定した 生産量を得るために必要である，作物の組合せによる 合理的な輪作の 基本は，イネ科作物一マメ科作物・葉菜 類・果菜類一根菜類であり ${ }^{(16)}$, 米国 ${ }^{(4)}$ 北部では大豆一トゥ モロコシ，南部では大豆ーワタの型で，中国東北地区 ${ }^{(13)}$ 北部では大豆一トウモロコシー小麦, 同南部では大豆一ト ウモロコシーコウリャンーアワなどが，わが国(16)では麦一 大豆の結びつきを基本として, 各地に特有な葉菜類, 根 菜類,タバコなどが組合されている. 大豆連作障害の主 因であるセンチュウは，イネ科作物には笴生しない。輪 作は 異作物栽培上からくる土壇養分の 収支ばかりでな く, センチュウ抑制の面からも合理的である(23).

\section{(2) 密植多肥栽培法（畦幅と播種量）}

多收檴栽培法の一つとして本法が用いられている. 大 豆の増収には単位面積当りの茎重を高め, 次いで粒茎比 を高めて子実を効率よく生産する必要がある(24 26). 大 豆は密植により草型がかわるが, 単位面積当りの株数の 多いことにより葉面積は増して，日射エネルギーの利用 効率は高まる.この場合, これら株数に対応した土壤盖 水分の供給が伴わない時には下葉が枯れ上がり, 体内養 分の低下により着萊や子実肥大が抑制され減収となる. 多肥は, このような密植による個体間の養分吸収の競合 を補おうとする方法である. 栽植密度は品種, 栽培地, 播種期, 機械化栽培の有無により異なり，米国では畦幅 と播種量を, 収量, 作業能率, 生産費の点から検討して おり ${ }^{(4)}$, 各国において密植多肥向品種が栽培され増収を あげている.

\section{(3) 水田転換畑栽培（土壇水分含量）}

大豆の生育には多量の水分を必要とするが, 直根が土 中深く入るため耐旱性は高い.土壤水分の保持は特に開 花後の粒肥大期において大切であり, 植物体成分の子実 への移行を容易にし (27), 百粒重や収量を増す要因となっ ている(4).このため, 米国・中国では灌水が考慮されて いるところもある ${ }^{(3,4,13)}$. 一方, 湿害が実際の栽培上問題 とされているものに, わが国の水田転換畑栽培がある. この栽培法は近年米の生産調整を目的として行なわれた ため普及は目覚しく, 1981 年には大豆総生産量の $68 \%$ が転換畑で生産されるようになった(1)。大豆の生育に好 適な地下水位は $50 \mathrm{~cm}$ 以下といわれているが，排水基 盤整備を行なわない転換畑では過湿な場合が多い. 品種 によっては土壤中の酸素不足により根に障害を起こし, 上層に多く根を張るために養分の吸収範囲が狭められ， 植物体の生育悪化が原因となり，不稔粒数を増すなど著 しい減収を招く ${ }^{28}$. 転換初年目では根粒菌の接種が必要 であり，過湿による病気も発生し易いが，七ンチュウの 害は受けない，転換畑土壤は保水力に富む肥沃な沖積土 壤の場合が多く, 排水が良好であれば普通畑に生育した 大豆に比べて登熟期の純同化率も高まり, 百粒重や収量 に増大がみられる。

\section{(4) 晚播栽培（播種期の移動）}

子実の収量確保には品種の持つ播種適期を守ることが 大切であるが, 気象災害や病虫害を回避したり土地を高 度に利用しょうとする場合には, 播種期移動に伴う減収 
程度とのか福要いに応じて，作付体系の中に播種期をか えて大豆が竦培されている(16)。たとえば，転換畑で麦一 大豆の作付体系で栽培する場合, 東海地方以北では麦の 収篗期の関係から晚播栽培にならざるをえない，播種期 の移動は開花までの日数を著しく短縮させ，基本栄盖生 長量の低下による節数の減少とそれに伴ら個体当りの莁 数の減少ぷ，収量を低下させる原因となっている．密植 により個体生育量の低下を補うとともに，個体生育量を 確保し易い長秙の中生〜晚生品種を選び，生育環境整備 飞努める必要がある(16)。なお，こ机ら栽培法によっても 一萊内粒数はかわらず，百粒重も極端な晩播以外はかわ らないといわ机ている。米国北部で澄芽, 開花, 成熟 に対する気温の影響が厳しく，適期播種が強調されてい $z^{(3)}$.

\section{4. 品種・栽培と子実の品質 - 加工適性との関連}

子実の品質・加工適性を外锤拉よび成分組成に分け， それらへの品種と裁培の影響を述べる。

\section{1) 外観への影響}

品種の特徴は, 種皮, 目 (へそ), 子葉の各色調, 粒の 大きさ (百粒重)，裂皮，乙わ，光沢などにみられる. 百 粒重は早生に比へて晚生品種に大粒の㑯向があり，好天 の年は粒が肥大し良質に，不順な年，とくに早害により 小粒化し，低品貿となる．晚播栽培で粒重が低下し，転

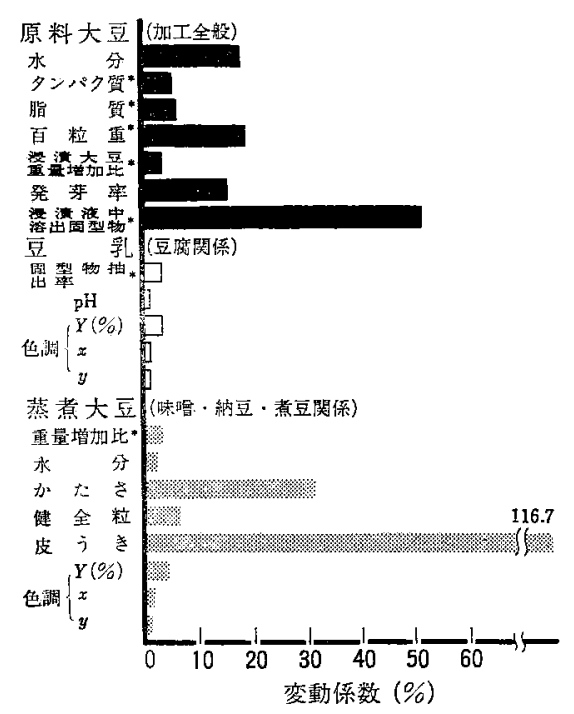

図 6 日本大豆の成分・加工適性の試料間変動 (105 棓料：60品種 7 系統)

*原料大豆乾物当的換算值
換畑栽培で肥大するが，品種によっては粒の肥大が裂皮 を生み品質が劣下する.このような外観上の変化は加工 適性に顕著に反映し，水浸濱中の原料の損失（浸漬液中 溶出固型物の增加)，加工作業上の支障之製品の品質劣 下（蒸煮大豆の皮うきくくすれ）など原因となる、日 本各地奨励品種の加工適性の試料間变動（図 6)(29) で は, 裂皮に伴ら加工浐性項目の変動が大きく, 品種また は栽培条件により影響を受け易い項目であることが理解 される。

\section{2）成分組成への影響 \\ (1) 品 種}

一般に，早生品種はタンパク質・灰分含量が高く，炭 水化物含量が低い傾向を，中生品種は中間的含量を，晚 生品種は早生品種之逆の傾向を示す ${ }^{(30)}$. こ礼5成分含量 の品種間美異については，光合成生産物蓄積期間が品種 により異なることから，光合成生産物含量に対するタン パ質・灰分含量の比率をるって説明することができ る(30). また, 他の要因としては, 一株粒重（一株につく 子実粒の重さ)於関保する。タンパク質や灰分は土堙か ら吸収された窒素やその他の無機成分上り作られ植物体 内涪積されるが，これら成分の子実への配分において, 一株粒重の低い早生品種汇高く，一株粒重の高い晚生品 種に低くなることは当然である(30).たとえば，九州産夏 大豆はタンパク質含量の高いことで知られているが，こ れは，極早生〜早生品種であり，一株粒重も低い(30).一 方, 脂質含量は登熟期間の温度の影響が大きく, 高温で 登熟する早生・中生品種の脂質含量は晚生品種より高 く, 脂肪酸組成もオレイン酸含量が増加しリノレン酸含

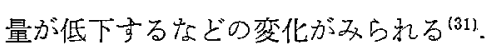

その济か，子実の成分組成は品種の植物体の伸育性に む左右される。たとえば，食品用大豆は輸入・国産大豆 ともに節別により粒の大きさを小粒, 中粒, 大粒儿調整 後, 加工目的にそって使われるが，こ礼ら各粒の分布割 合および成分組成には品種からの著しい特徽が みられ る 質, 脂質合量が低く, 炭水化物含量が高いなどの特徵が みられるまた，成分含量の差異は脂質や脂肪酸組成に おいて著しく，小粒となるに伴い脂質やオレイン酸合量 が低下し、リノレン酸含量に増加の現象がみられる。こ れらの原因についてかが国の有限・無限両伸育型品種学 
用いて検討した結果，無限伸育型品種において後期に開 花結実した子実粒が，登熟日数の短縮と登熟期間の気温 の低下が原因となって，小粒化とともに，脂質含量拈よ び脂肪酸組成に変化が現われたものと考察された ${ }^{(12)}$.わ が国の栽培品種の多くは有限伸育型のため粒の大きさの ばらつきや成分組成の差異は少ないが，米国，中国では 無限伸育型品種の栽培が多く，上記の現象が顕著にみら れ，実際には小粒部分を原料とする納豆において未熟粒 をはじめ原料大豆の品質が問われる理由ともなっている.

\section{(2) 栽培環境条件}

栽培地，栽培年の気象条件の影響としては，日長や気 温の差異により大豆の生育や作柄が変化し ${ }^{(34)}$, 子実成分 に影響を及ぼす。たとえば，温暖な年に生産された子実 は冷涼な年のそれに比べてタンパク質，脂質，灰分含量 が高く, 炭水化物含量が低く ${ }^{(12,32)}$, 脂肪酸組成ではオレ イン酸含量が高くリノレン酸が低いなど，脂質含量とと もに大豆油の品質も向上し，栽培年の羑がみられる ${ }^{(12)}$. また，煮豆の軟かさと関係があるといわれるカルシウム 含量は栽培中の高温により增加し(35)，さらに，味噌の色 調に深く関連するカロチノイド含量も品種とともに栽培 年の影響を受ける(36)。しかしながら，これら栽培年から の影響の程度を品種からのそれと比較した場合，各成分 含量は品種からの寄与が大きく，栽培年からの影響を受 ける成分は, 脂質, オレイン酸, リノレン酸, カルシウ ムの各含量に過ぎず（表 3)，このことから，原料大豆の 品種選沢の重要性が理解される(37).

栽培地の影響としては，米国南部栽培大豆の脂質含量 が高く，脂肪酸組成においてもオンイン酸が高くリノレ ン酸に低い傾向がみられるが(10)，これは，品種特性とと もに, 登熟気温の影響によると考えられ，一方, 北部栽培 大豆のタンパク質含量に高い傾向のみられることは(11)， タンパク質含量と脂質含量が負相関(30)を示すことから，

\section{表 3 大豆の化学成分と品種および栽培年の影響}

\begin{tabular}{|c|c|c|c|c|c|c|c|c|c|}
\hline \multirow{2}{*}{\multicolumn{2}{|c|}{ 成 }} & \multirow[b]{2}{*}{ 分 } & \multicolumn{2}{|c|}{ 寄与率 (\%) } & \multirow[b]{2}{*}{ 成 } & \multirow{2}{*}{\multicolumn{2}{|c|}{ 分 }} & \multicolumn{2}{|c|}{ 寄与率 (\%) } \\
\hline & & & 品種 & 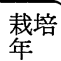 & & & & 品種 & $\begin{array}{l}\text { 截培 } \\
\text { 倍 }\end{array}$ \\
\hline タ & V, & 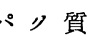 & 88.5 & 2. 3 & 炭 水 & 化 & 物 & 59.4 & 35.7 \\
\hline 脂 & & & 24.6 & 62.8 & 灰 & & 分 & 38.8 & 28.5 \\
\hline パ & $v ミ$ & チン酸 & 22.0 & 18.7 & カ & ウ & 么 & 31.1 & 19.5 \\
\hline ス & テア & リン酸一 & -18.1 & 16.5 & リ & & ン & 13. 7 & -2.4 \\
\hline オ & $v 1$ & イン酸 & 13.8 & 68.3 & マグネ & シウ & ム & 41.0 & 24.2 \\
\hline リ & ノ- & 一ル酸 & 69.9 & 2.4 & カル & ウ ウ & 么 & 23.4 & 62.9 \\
\hline リ & $>2$ & ンン 酸 & 12.6 & 77.4 & 全カ口 & チノイ & ド & 73.2 & 3. 7 \\
\hline
\end{tabular}

登熟気温の低いことによる脂質含量の低下と考えられて いる(10,12).

\section{(3) 栽培方法}

密植多肥栽培においては，子実成分組成への施肥反応 はにぶく，極端なやせ土壌での栽培を除いては，正常な 肥沃度で 施肥(38,39)や肥沃度を大きくかえても，子実成 分には著しい影響のないことが認められている。一方, 栽植密度の 影響は, 密植によりタンパク質含量に 增加 之, 脂質・炭水化物・灰分含量に減少の傾向がみられて いる(40).この理由としては, 密植による主茎長の徒長が 過繁茂と陰葉化を招き，日光の透過度の低下が光合成生 産物の脂質・炭水化物の子実中蓄積量を減退させるため に，逆にタンパク質含量が高まったものと解釈されてい る(40). さらには，密植による植物体の徒長が一株分枝数 を減少させ，これが一株稔実萊数の低下となり一株当り の子実生産数を低下させるために，子実一粒当りの分配 タンパク質が增加したものと考兄られている(40).

土壤水分の影響を，先に述べた水田転换畑栽培子実の 成分組成についてみると，普通畑栽培子実に比べて水分 含量に多い傾向 ${ }^{(41)}$ があるが，一般成分・無機成分・脂肪 酸組成に有意差はなく，成分上の唯一の違いは転換烟栽 培子実のマンガン含量が高いことである(42)。この理由と しては，水田土壤が還元状態であるためマンガンが活性 化し，植物体によく吸収されたためと考学られる(42).

なお，転換畑大豆の流通量の増大に伴い，加工適性明 確化の要望も多い，前述のごとく，転換畑大豆は百粒重 が增し，蒸煮大豆の赤みの鮮かさや讶えに低下がみられ る.また，原料大豆の水分含量が多いことにより，蒸惹 大豆の重量増加比や水分含量に減少の傾向がある. しか しながら，加工適性評価（豆腐・味噌・納豆・煮豆）に おいて品種と栽培条件（転換烟栽培）を比較した場合， 原料大豆の水分含量を除いて品種からの影響（寄与率） が著しく大きく，栽培条件の影響はほとんぞ認められな いことが明らかとなっている(41).

播種期の影響としては，晚播栽培のごとく播種期をか えた場合，脂質含量や脂肪酸組成の変化 (品質低下) ${ }^{(31)}$ と同時に，子葉の色調が晚播とともに増大し (43)，味噌の 色調に影響するものと考兄られる。

わが国の大豆需給の現状に立って, 品種改良や栽培上 


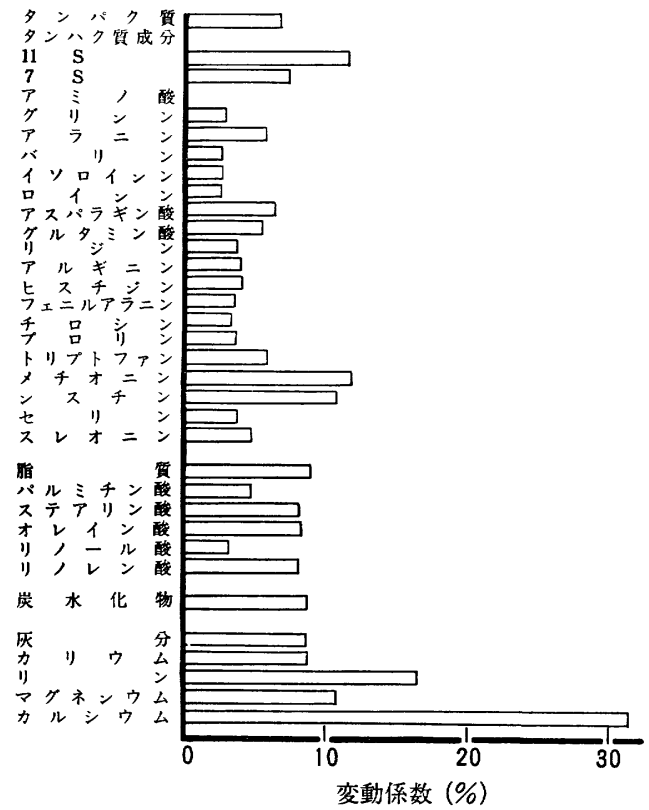

図 7 大豆の化学成分の品種間変動

の問題点を品質・加工適性を加味して述べた，食品加工 原料としての大豆は, 外観上の特徵に加えて品質, とく に成分組成が品種と栽培上の諸要因の影響を受け，成分 の種類により特徴ある変動を示す(30,44 49)（図 7)。これ ら成分の変動要因を品種と栽培地（栽培地からの諸栽培 要因）に分けて検討し，それぞれの寄与率(48)で示すと 表 4 のようになる.これらの結果は, 成分の変動要因を 示すばかりでなく，子実の利用加工上の個々の成分につ いての選択基準とすることもできる.すなわち, タンパ ク質, タンパク質成分組成，アミノ酸，脂質，子葉の色 調などを問題とする場合には品種の選択が重要であり， 炭水化物，灰分，無機成分の場合には栽培条件の考慮が 必要となる，さらに，脂質・脂肪酸組成は，品種ととも に栽培年や栽培地の気象条件の影響を考慮する必要があ る(12) (表 3).これら品種の影響を受ける成分は品種から の寄与率が他からの寄与率よりも非常に大きく，環境要 因により容易に変動せず(12,48), ここに有種の重要性があ る. また，食品用大豆としての加工適性においても，原 料大豆から成分を抽出する豆腐などのような利用形態で は，その加工適性の品種間変動はいずれも小さいが，味 噌・納豆・煮豆製造のごとく丸大豆としての利用形態で は品種間差異が著しい(29,41)（図6）。これらは栽培条件
表 4 大豆の化学成分と品種および栽培地の関係

\begin{tabular}{|c|c|c|c|c|c|c|}
\hline \multirow{2}{*}{ 成 } & \multicolumn{2}{|c|}{ 寄与率 (\%) } & \multirow{2}{*}{\multicolumn{2}{|c|}{ 成 }} & \multicolumn{2}{|c|}{ 寄与率 (\%) } \\
\hline & 品種 & 栽培地 & & & 品種 & 栽培地 \\
\hline タンパク質 & 55.4 & 18. 3 & チロシ: & & 31.1 & 7.2 \\
\hline タンパク質成分 & & & プロリ: & & 34.7 & -0.6 \\
\hline $11 \mathrm{~S}$ & 58.8 & 5.7 & トリプトフ & 7 & 38.5 & 13.8 \\
\hline $7 \mathrm{~S}$ & 35.9 & 1.4 & & & & \\
\hline ア ミノ酸 & & & メチオ & ソ & 48.5 & 4. 3 \\
\hline グリシン & 62.6 & 0.8 & シス チ & & 50.2 & 17.0 \\
\hline $\boldsymbol{\gamma} \bar{\gamma}=$ ข & 35.6 & -1.1 & 七 リ : & & 48.0 & 0.5 \\
\hline バリ リ & 36.6 & -0.5 & スレオ=: & ン & 39.2 & 4. 6 \\
\hline イソロイシン & 61.8 & 0.7 & & & 73.8 & 8.2 \\
\hline ロイシン & 56.0 & 1.9 & 炭 水 化 牛 & & 30.7 & 47.0 \\
\hline $\begin{array}{l}\text { アススパラギン } \\
\text { 酸 }\end{array}$ & 77.0 & 0.6 & $\begin{array}{llll}\text { 灰 } & & & 5 \\
\text { カ } & \text { リ } & \text { ウ } & \end{array}$ & & $\begin{array}{r}19.6 \\
7.7\end{array}$ & $\begin{array}{r}66.5 \\
3.3\end{array}$ \\
\hline グルタミン酸 & 61.6 & 3.0 & リ & ン & 9.0 & 72.0 \\
\hline リ シ ン & 56.5 & 4.6 & マグネシウ & ム & 29.8 & 37.2 \\
\hline アルギニン & 36.9 & 16.5 & カルシウ & & 11.4 & 67.1 \\
\hline ヒスチジン & 35.1 & 1.1 & & & & \\
\hline $\begin{array}{l}\text { フェニルアラ } \\
\text { ニン }\end{array}$ & 62.4 & 2.3 & & & & \\
\hline
\end{tabular}

の影響を受けずに ${ }^{(41)}$ 品種固有の性質をもち, 加工適性 の立場からも育種による品種改良の重要性が栽培条件の それに優ることが認められている。

以上述べた諸知見は大豆に備わった性質であり，輸 入・国産を問わず原料大豆選択の際の基準となりうるも のと考える．参考としていただければ幸いである.

\section{文献}

1）農林水産省農虫園芸局畑作振興課：“大豆に関する資料”, 1982.

2）橋本鋼二 : “大豆の生態と栽培技術”, 斎藤正隆・大久保隆 弘編著, 農文協, 1980, p. 44.

3）川島良一：“のびゆく技術 13”，国際食糧農業協会，1965.

4) E. E. Hartwig : "Soybeans", ed. by B.E. Caldwell, American Society of Agronomy, Inc., Publisher, Madison, Wisconsin, USA, 1973.

5）昆野昭晨 : “作物の育種一その回顧之展望”, 農林省農林 水産技術会議事務局編，1977，p. 301.

6) American Soybean Association : "Soya bluebook", 1982 , p. 17.

7）アメリカ大豆協会: “食品用アメリカ大豆”, 1980.

8）中村 博: “大豆の経済”, 幸書房, 1976.

9）平 春枝: 大豆月報, 9, 19 (1979).

10）平 春枝, 平 宏和: 日食工誌, 22, 42 (1975).

11）平 春枝, 平 宏和: 日食工誌, 23,6 (1976).

12）平 春枝, 平 宏和, 斎藤正隆: 日作紀，43，482(1974).

13）橋本鋼二：農業技術，33，433(1978).

14）松本重男 - 大庭寅雄 : “総合野菜・畑作技術事典 I ”, 農林 省農林水産技術会議事務局編, 1973, p. 100.

15）松本重男 : “総合野菜, 畑作技術事典III”, 農林省農林水産 技術会議編，1973，p. 273.

16）大久保隆弘：“大豆の生態と栽培技術”, 斎藤正隆, 大久保 隆弘編著, 農文協, 1980, p. 102，187。

17）小島睦男, 福井重郎, 渡辺 孷: 日作紀, 33, 437(1965). 
18) J. C. Lyons \& E. B. Earley : Soil Sci. Soc. Am. Proc., 16, 259 (1952).

19）海妻矩彦，江川雅德：日本作物学会東北支部会報, No.17, 60 (1975).

20）青木弘二: 農業及園芸, 25，786 (1950).

21）山木鉄司：農業及園芸，26，467 (1951).

22）大久保隆弘：“日本の大豆”, 農林省農虫園芸局畑作振興課, 同流通局食品油脂課監修, 地球社, 1977, p. 214 .

23）尾崎 薰：北農試研報，74，1 (1969).

24）川島良一：“大豆 2 ”, 農業技術協会, 1961，p. 5 .

25）川島良一, 丸山宣重, 杉山信太郎, 御子柴公人, 松沢 宏: 長野農試集報, 5, 55 (1962).

26）御子柴公人: “ダイズの作り方”, 農文協, 1975, p. 59.

27）浦野啓司, 長瀬嘉迪, 小口忠彦: 日作紀, 27，315(1958).

28）福井重郎, 伊東隆二, 内山泰孝 : 関東東山農試報, No.1, 9 (1951).

29）平 春枝: 食総研報, No. 40,35 (1982).

30) H. Taira \& H. Taira : Proc. Crop Sci. Soc. Japan, 40, 530 (1971).

31）平 春枝, 平 宏和, 鳥生久嘉：日 作 紀，47（別 2)，33 (1978).

32）平 春枝, 平 宏和, 斎藤正隆 : 食 総 研 報, No. 29,27 (1974).

33）平 春枝, 平 宏和, 紊藤正隆: 日作紀, 46, 483(1977).

34）山内富士雄 : 北農試菓報, 98, 12 (1971).

35) J. I. Cartter \& T. H. Hopper : U.S. Dept. Agr. Tech. Bull., No.787, 66 (1942).

36) 平 春枝, 平 宏和, 御子柴公人: 日作紀, 50, 98(1981).

37）平 春枝: 農業及園芸, 53，303 (1978).

38）赤城仰哉, 佐々木紘一：北農試集報, 14, 41 (1964).

39) N. J. Viljoen : Union So. Africa Dept. Agr. and Forestry Sci. Bull., No.169, 68 (1937).

40）平 春枝, 平 宏和, 松川 勲, 三分一 敬, 堀江正樹: 日作紀，49，205 (1980).

41）平 春枝, 高城英雄, 国分喜治郎, 小山悬雄, 星野四郎, 宮内直利：日作紀, 51 (別 2), 67 (1982).

42）平 春枝, 平 宏和, 小沢栄二, 佐々木邦年: 日作紀, 46, 103 (1977).

43）平 春枝, 平 宏和, 鳥生久嘉: 日 作紀, 48 (別 2), 61 (1979).

44）農林省食品総合研究所：食糧, No.17, 11 (1975).

45) H. Taira \& H. Taira : Proc. Crop Sci. Soc. Japan, 41, 213 (1972).

46) H. Taira \& H. Taira : Proc. Crop Sci.Soc. Japan, 41, 235 (1972).

47) H. Taira \& H. Taira : Proc. Crop Sci.Soc. Japan, 42, 185 (1973).

48）平 春枝, 平 宏和: 食総研報, No.29, 21 (1974).

49）平 春枝, 平 宏和: 食総研報, No.30, 33 (1975).

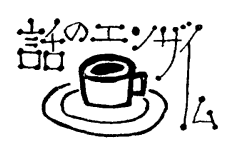

\section{新 薬 開 発 余話}

製薬会社の立派な研究所をみると，薬の素人さんはそ の研究所の中で幾多の優れた頭脳が集結して新医薬品が デザインされ，続々と創製されていると思ららしいが， 実際はそう生易しいものではない，優れた頭脳が集まっ てまでは本当であっても, そら簡単に薬はできるもので ない。

クロルプロマジンは抗精神病薬（メジャー・トランキ ライザー) の始まりとして画期的な薬である. 1950 年<smiles>CCCCCCCCN1c2ccccc2Sc2ccc(Cl)cc21</smiles>

クロルプロマジン

代, フランスの外科の軍医 Laborit は, 外科ショック防 止には生体すべての働きを遮断することが必要であると 考古，種々の薬を配合し，“cocktail lytique”（遮断カク テルともいうべきか）を作り，たまたま抗ヒスタミン薬 のプロメタジンが有効であることを知った。ローヌ・プ ーラン社研究陣は Laborit の要望に応觉, フェノチアシ ン系化合物を徹底的に調ベ，クロルプロマジンを見いだ したのである. Laborit は外科的ショックが精神病に類 似するという想定より，外科的ショックに効くクロルプ ロマジンは精神病にも効くはずであるとしたが，実際に 臨床治験によりクロルプロマジンは精神病に著効を示す ことが明らかとなったのである.

ロシュ社の化学者 Sternbach は 1950 年代後半に, か つてポーランドの大学に打いて扱った化合物群の中から 良いトランキライザーを探そうとした．数々の化合物か らは期待できる薬理作用が発見されなかったが，最後の 